\title{
MARKETING AWARENESS OF CROSSBORDER DESTINATION - THE CASE STUDY OF BIHOR- HAJDU/BIHAR EUROREGION
}

\author{
Corina-Florina TĂTAR* \\ University of Oradea, Department of Geography, Tourism and Territorial Planning, \\ Universității Street, 1, 410087, Oradea, Romania, e-mail: corina_criste_78@yahoo.com
}

\section{Tomasz STUDZIENIECKI}

Gdynia Maritime University, Department of Management and Economics, Morska 81/87, 81-225 Gdynia, Poland, e-mail: tomaszstudzieniecki@wp.pl

\begin{abstract}
Klara CZIMRE
University of Debrecen, Department of Social Geography and Regional Development Planning, Egyetem tér 1, 4032, Debrecen, Hungary, e-mail: czimre.klara@science.unideb.hu
\end{abstract}

Janos PENZES

University of Debrecen, Department of Social Geography and Regional Development Planning, Egyetem tér 1, 4032, Debrecen, Hungary, e-mail: jpenzes@unideb.hu

\begin{abstract}
Citation: Tătar, C.F., Studzieniecki, T., Czimre, K. \& Penzes, J. (2020). MARKETING AWARENESS OF CROSSBORDER DESTINATION - THE CASE STUDY OF BIHORHAJDU/BIHAR EUROREGION. GeoJournal of Tourism and Geosites, 28(1), 95-103. https://doi.org/10.30892/gtg.28107-454
\end{abstract}

\begin{abstract}
The study aims to highlight the high education students' awareness about the tourism opportunities of the Bihor-Hajdu-Bihar euroregion of north-western Romania and eastern Hungary respectively, through a survey applied to the students of the University of Oradea and Debrecen cities, as county seats of the of Bihor and HajduBihar. The respondents' answers were stored into an SPSS database and its results processed and analyzed through generated charts. The results showed that most respondents claim for a better marketing of the euroregion and its activities, through internet and websites, indicating an eagerness to find out more about its potentialities. Most respondents were aware of the tourist attractions that the county from their side of the border offers, but only five respondents could provide tourist attractions that belong to the other side of the border, thus indicating that the euroregion is not yet perceived as a single tourist destination on the market. Therefore $79,7 \%$ of the respondents could name correctly one tourist attraction that belongs to the euroregion, more than half $(67,2 \%)$ could provide two attractions and less than a half $(40,6 \%)$ could provide three tourist attractions as incentives for visitation and marketing.
\end{abstract}

Key words: borderland, tourism, Bihor-Hajdu Bihar euroregion, marketing, awareness

\footnotetext{
* Corresponding author
} 


\section{RESEARCH PURPOSE}

The current study is meant to highlight the high education students' awareness about the tourism opportunities of the Bihor and Hajdu-Bihar areas as adjoining borderland counties that belong to north-western Romania and eastern Hungary respectively and to highlight the degree of knowledge of the Bihor-Hajdu Bihar euroregion generally among the young population that inhabit this area.

Therefore a set of closed and open question surveys were applied in the core centres of the Bihor-Hajdu Bihar euroregion, namely Oradea city (Romania) and Debrecen city (Hungary) to the students of the University of Oradea and of the University of Debrecen. The research results are meant to help potential investors in tourism in the two counties as well as researchers interested of developing joint projects between the two high education institutions.

\section{KNOWLEDGE OF THE TOPIC IN INTERNATIONAL LITERATURE}

Tourism in crossborder areas is approached by more authors (Studzieniecki \& Spiriajevas, 2019; Wecka, 2013; Thimothy \& Saarinen, 2013; Thimothy \& Teye, 2008; Wachowiak, 2006). The most common elements in tourism considered in cross-border cooperation include trade in goods and services, promotion and marketing, flow of people, environmental conservation, transportation and infrastructure (Thimothy \& Teye, 2008). Crossborder tourism marketing is a relatively new trend, which comes to the forefront in the globalizing era as tourism is seen as a means to join people because tourist flows do not stop at the borders but with a good promotion and management allow mutual exploration, cultural exchanges and knowledge enhancement.

Crossborder cooperation in Central and Eastern European former communist countries comes to the forefront in the economic, social and political sphere as a modern trend of changing the borders' role from divergent separation into convergent connecting lines (Studzieniecki \& Soares 2017; Ilieș, 2003), one of its stated objectives being to prevent the isolation of border areas (Czimre, 2010; Lorant et al., 2011, 2008), as in the case of the Bihor- Hajdu-Bihar Euroregion herewith submitted for analysis. The current study focuses on raising awareness of Bihor-Hajdu Bihar borderland tourism. Tourism joint projects have become very active lately thus resulting in a free flow of people and goods, academic exchanges, networking at institutional levels, joint project accomplishments, environmental protection measures, etc. The current study fills the gap of crossborder researches related crossborder marketing awareness.

Euroregions are small areas or regions reaching beyond political frontiers to work with adjacent areas or communities on the other side to address common social, economical and technical issues in borderlands (Thimothy \& Saarinen, 2013). Inter-local cooperation or euroregions have gained momentum in Europe in the 1990s -2000 amounting to 74 such structures currently (Thimothy \& Saarinen, 2013). There are many examples around the globe where many countries with neighbouring protective areas have joined hands to reverse the adverse impacts, being not only beneficial for the environment as it also encouraging friendly and co-operative relations between countries (Wachowiak, 2006). The study herewith encapsulates a research among students of the crossborder area Bihor-Hajdu Bihar from Oradea and Debrecen as core centres of the euroregion, meant to highlight the knowledge and awareness of the euroregion existence and its tourist attractions so as to create a cooperative alliance of the people in the region (Uzama, 2011). The euroregion submitted for study herewith is an area where cultural and natural areas lie adjacent to the Romanian and Hungarian border of north-western Romania and eastern Hungary epitomized in many natural reserves, cultural and entertainment sites, some of which were highlighted by the survey respondents. 
Borderland tourism opportunities and tourist flows can enhance by making its people aware that they belong to a rich natural and cultural environment.

Because of their peripherality, borderlands are often more physically underdeveloped and ignored by mainstream marketing, despite their considerable potential, this study being meant to bring added value so as to help promote the attractions of these two neighbouring countries as a single integrated tourist destination. Tourism as the tertiary sector of the economy is a source of revenue and most tourist destinations will attempt to capture tourist flows, which are not oriented randomly toward certain destinations but as a consequence of the effort of certain states policies and planning strategies (Hall, 2008; Maghsoodi Tilaki et al., 2017). A sustainable marketing uses resources sustainably, reduces overconsumption and waste, maintains diversity, integrates tourism into planning, supports local economies, involves local authorities, consults stakeholders and the public, markets tourism responsibly (Holloway, 2004), preserving naturally endowed areas sustainably without damaging its ecological balance (Dasgupta, 2011). Marketing sustainably means to anticipate demand, recognize it, stimulate it and finally satisfy it (Fyall \& Garrod, 2005).

\section{METHODOLOGY}

In order to meet the research goal a set of surveys were applied to the students of the high education institutions of the Universities of Oradea and Debrecen, as main cities and county seats of the two neighbouring counties of the Bihor-Hajdu Bihar euroregion.

The survey comprises seven questions referring to the age; definition of a euroregion; selection of the right euroregion to which their city belongs; naming at least three main attractions that belong to the euroregion; naming activities carried out within the euroregion; the students opinion referring to marketing the euroregion and the best distribution channel for it. The survey was applied in November and December of the year 2018 at the University of Debrecen (Hungary) and in the month of January 2019 at the University of Oradea (Romania). The respondents' answers were stored into an SPSS database and its results processed and analyzed through generated charts.

\section{RESULTS}

The survey respondents were aged between 21-30 years and are students of the Universities of Oradea (Romania) and Debrecen (Hungary) at various specialisations. The first question of the survey was meant to find out the respondents knowledge of a euroregion and how they define it (Figure 1); most Romanian (46,7\%) and Hungarian $(44,1 \%)$ respondents stating that it is a cooperation structure on both sides of the border and only $10 \%$ of the Romanian and 5,9\% of the Hungarian respondents stated that they do not know. Related to the question about the appurtenance of their city to a given range of euroregions (i.e. Carpathian, Danubian, Bihor-Hajdu Bihar, Cris-TisaMures) most respondents correctly indicated the belonginess of Oradea and Debrecen cities to Bihor-Hajdu Bihar euroregion, namely $76,5 \%$ Hungarians and $73,3 \%$ Romanians (Figure 2). As it can be shown from the chart below most respondents correctly matched their city to the right euroregion (i.e. Bihor-Haju-Bihar) which indicates a good knowledge of their local horizon and the appurtenance to the right cross-border structure, apart from a few cases who stated that their city belongs to the Carpathian, Danubian or Cris-Tisa-Mures euroregions.

The Bihor-Hajdu-Bihar Euroregion is located in the western part of the Romanain western hills, plain and partly the Carpathians and on the eastern side of the Pannonian Plain and encapsulates a Bihor-named Romanian county and a HajduBihar-named Hungarian county. Its population counts approximately 1,094,573 
inhabitants spread over $13,755 \mathrm{sq}$. $\mathrm{km}$. The main county seats of the euroregion are Oradea and Debrecen which are located at $80 \mathrm{~km}$ apart from each other. The euroregion has a judicial status, founded by the Local Council of the Municipality of Oradea and the Bihor County Council and its stated objective is to promote social and economic development as written on the official website of the Bihor County Council.

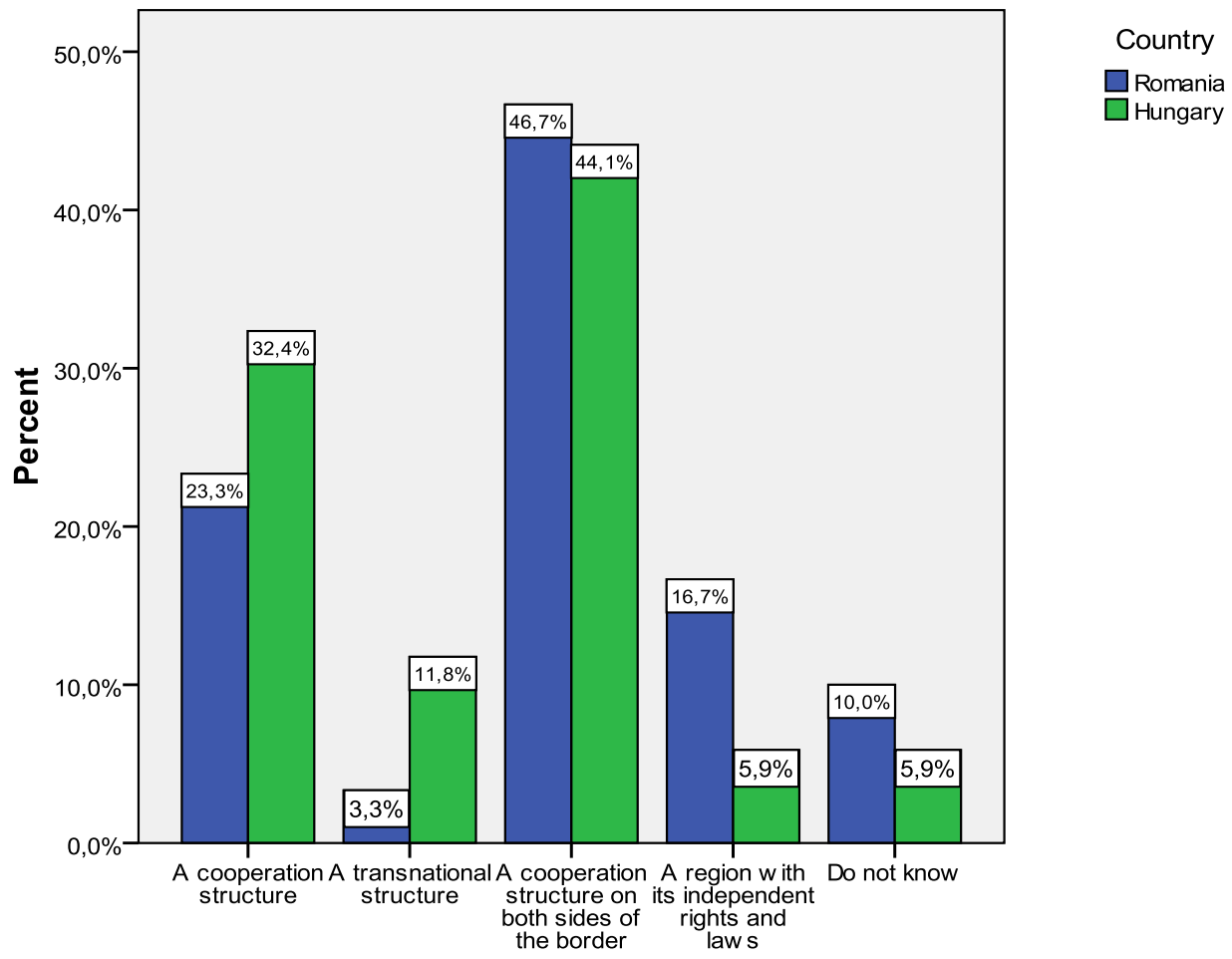

How would you define a euroregion?

Figure 1. Respondents' definition of the euroregion

(Source: Authors' survey applied in December 2018 and January, 2019)

Related to its tourism, the total accommodation capacity of the euroregion is of 12,000 beds with $80 \%$ on the Romanian side and its visitation frequency of 50,000 persons, equally spread in the two counties. The length of stay is 4.25 days in HajduBihar and 3,5 days in Bihor County (Badulescu \& Badulescu, 2008). The spas of Felix and 1 Mai from Romania and Hajduszoboszlo from Hungary capture most tourist flows of the euroregion (Tatar et al., 2013). Further on the respondents were asked to name from their own knowledge at least three tourist attractions of the euroregion (Figure 3) they belong to and the responses varied from the most accurate to those that are completely outside the limits of the euroregion, nonetheless most of the respondents naming attractions that belong to their side of the border, mostly placed locally in their city of residence, Debrecen or Oradea. As far as correct answers are concerned, only one Hungarian respondent indicated the tourist attraction of Felix spa as belonging to the Romanian side of the euroregion and four Romanians indicated attractions that belong to the Hungarian side of the euroregion such as Aquaticum Debrecen; Hortobagy National Park and the Hajduszoboszlo spa which appeared as most popular, a rate which indicates rather a low knowledge of attractions that belong to the foreign neighbouring county. 
A common mistake was to include Balaton Lake and the Danube as natural attractions of the euroregion which was indicated both by the Hungarian and Romanian respondents alike. From the man-made attractions, Gyula castle and Fisherman bastion of Budapest were indicated by some respondents which are outside the range of the euroregion as well as Mocanita (tourist train) and Viseul de Sus which are located outside the limits of the Bihor-Hajdu-Bihar euroregion.

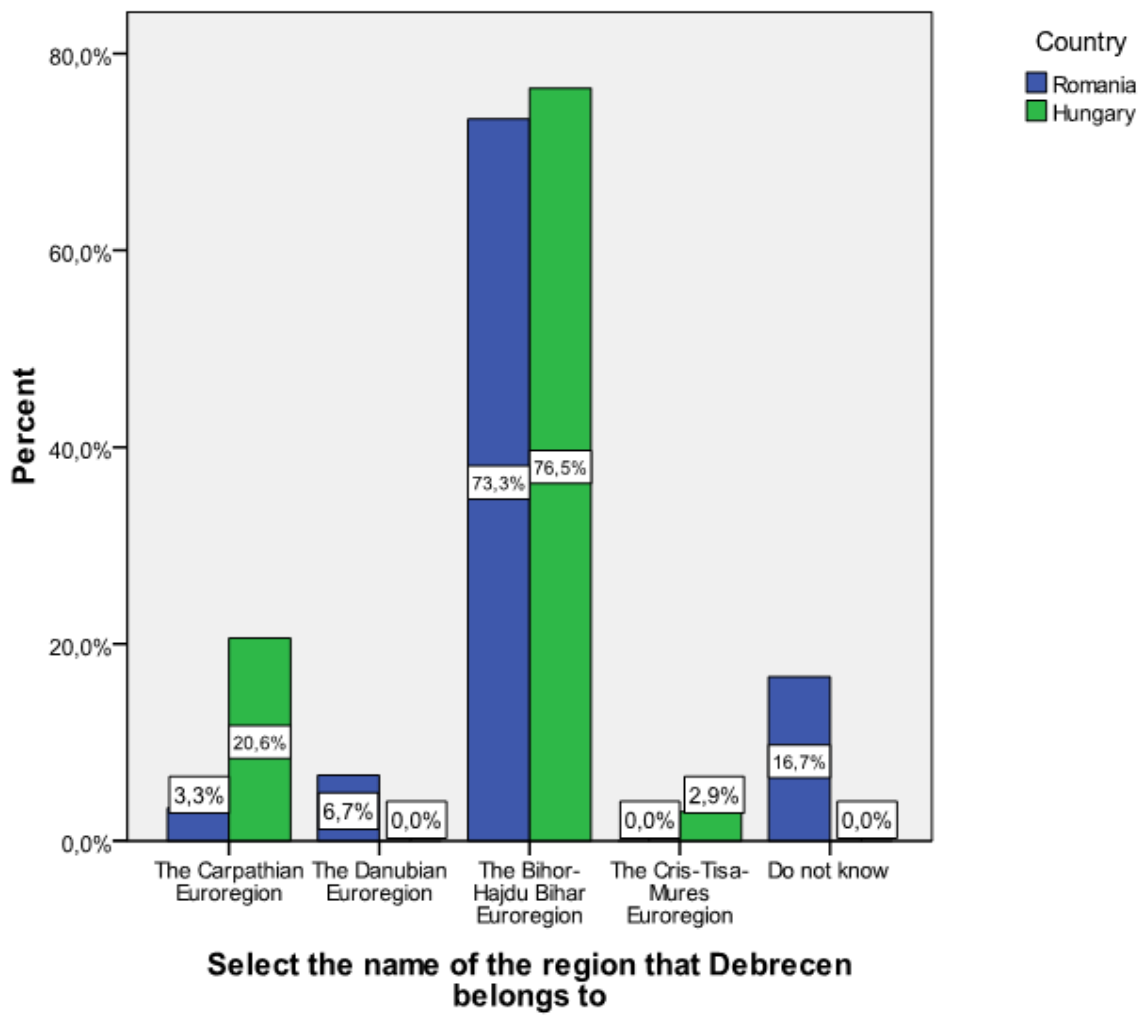

Figure 2. Respondents' answers in relation to the cities of Debrecen and Oradea appartenance to a euroregion (Source: Authors' survey applied in December 2018 and January, 2019)

Apart from these occurrences most respondents correctly indicated attractions that belong to the euroregion such as: Felix spa; Hajduszoboszlo spa; Aquaticum Debrecen; Nymphaea Lotus Aquapark Oradea; the Nature park of Cefa; Hortobagy National park; the Secession architecture of Oradea. Only by looking at the indicated attractions, it can be noted the similarity of attractions on both sides with thermal spas, aquaparks and nature parks as the most popular. Furthermore The Great Reformed Church of Debrecen appeared repeatedly as a popular sight of the euroregion referring to the man-made attractions. So as it can be noted the respondents are familiar with the most popular attractions belonging to the euroregion which highlighted once again a high concentration of man-made (cathedrals, churches, palaces and other monuments) resources as well as natural ones with nature reserves (Ilies et al., 2015), all having a touristic importance in the euroregion (Badulescu \& Badulescu, 2008). The indicated attractions are spread over the respondent's side of the border, which is a shortcome that could be overcome by promoting the euroregion as an integrated tourist destination in the future and which would create a better awareness of the attractions in its whole. 


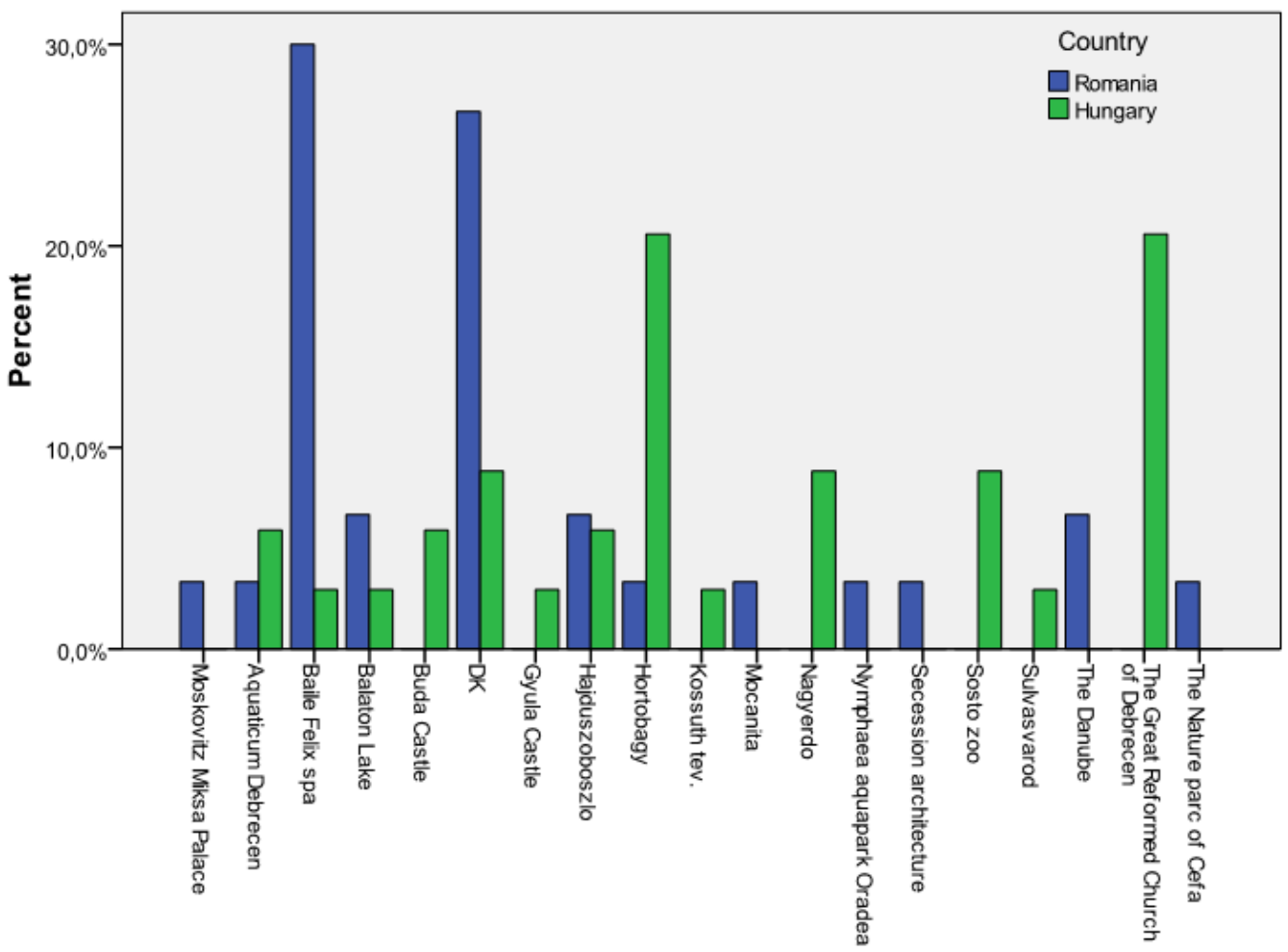

Can you name some tourist attractions that belong to the Euroregion ...

Figure 3. Respondents' answers in relation to the tourist attractions belonging to the Bihor-Hajdu Bihar euroregion (Source: Authors' survey applied in December 2018 and January and February, 2019)

Almost half of the questioned respondents (40,6\%) could provide three attractions that belong to the euroregion of Bihor-Hajdu Bihar; more than half $(67,2 \%)$ could provide two attractions and the largest share of $79,7 \%$ could name one tourist attraction that belongs to the euroregion. Apart from the secluded occurrences when some general attractions were wrongly integrated (i.e. The Danube, Gyula, Balaton Lake, Buda Castle, Mocanita) to the euroregion of Bihor-Hajdu Bihar, most respondents could provide correct attractions belonging to the euroregion they reside in, mostly on their side of the border. In relation to the respondents' awareness of the activities carried out within the euroregion (Figure 4), the largest share responded that they do not know which activities are carried out and only 13,3 \% of the Romanian respondents provided answers such as the Festival of Flowers held between 18-22 August and Secession tours of Oradea city and $2,9 \%$ of the Hungarian respondents could provide a positive answer, a fact which indicates a low knowledge of the practical activities unfolded in the Euroregion, thus their visibility and popularisation needing improvement.

The last two questions of the survey referred to marketing the euroregion and selecting the most appropriate channel of distribution (Figure 5 and Figure 6), the largest share of Hungarian (80\%) and Romanian (94,1\%) respondents answering that more marketing is necessary and the best channel for this marketing should be the internet and websites, indicated by a ratio of $97,1 \%$ of the Hungarian and $93,3 \%$ of the Romanian respondents. No respondent selected the radio as a best means of promotion and to a very little extent the TV $(2,9 \%)$ and leaflets and brochures $(6,7 \%)$ were selected. 
As the current research indicates, it shows that the euroregion is not marketed enough, $87,5 \%$ of respondents (Romanian and Hungarian put together) stating that more marketing of the euroregion should be done. Some studies (Badulescu \& Badulescu, 2008) claim as a solution to this shortcoming a common brand of the euroregion that will promote a unity in diversity, capitalising on the identity features of the region, a destination brand that will be advertised by national and local offices and involved operators (Badulescu \& Badulescu, 2008). According to the aforementioned authors the euroregion as a destination (Studzieniecki, 2005) will be easier to stand out and sell on the touristic market. The marketing should be done, as indicated by the majority of respondents with the latest means and technology, internet and websites being the best tool for this endeavour.

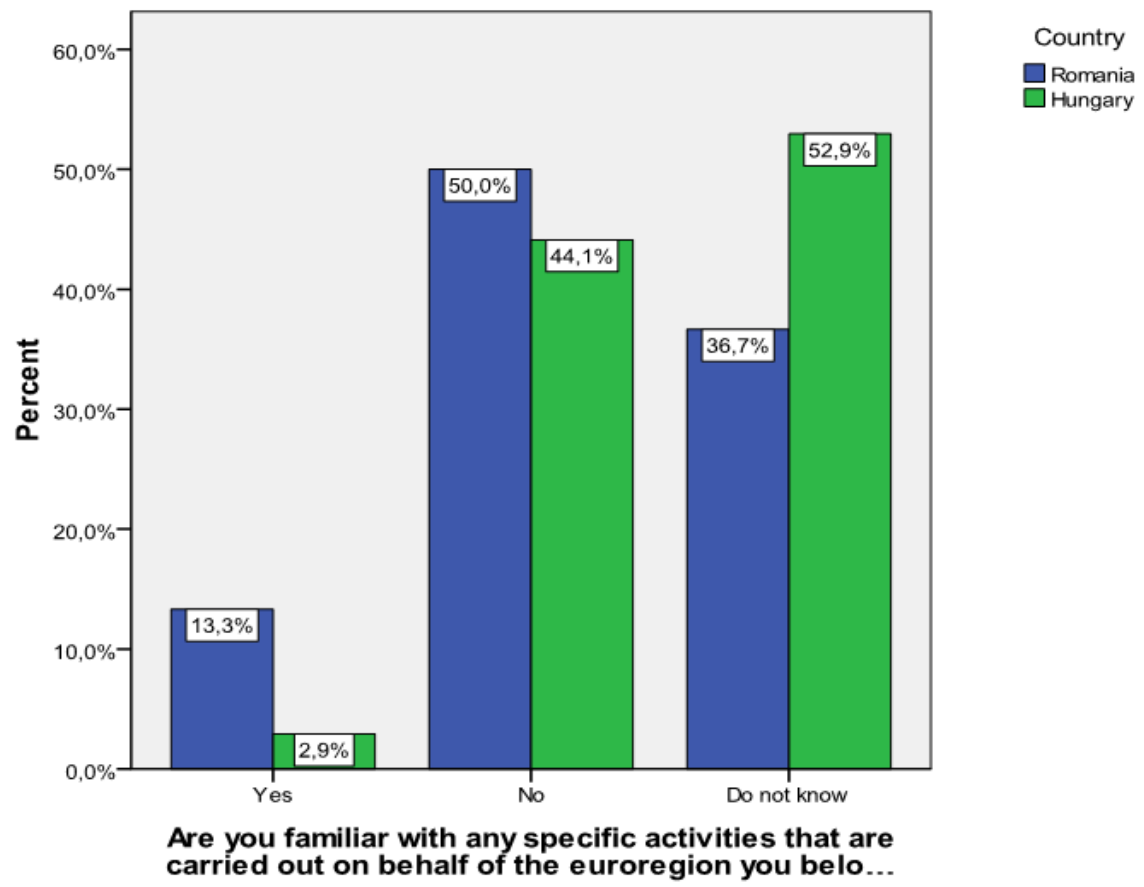

Figure 4. Respondents' answers in relation to activities carried out within the Bihor-Hajdu Bihar Euroregion (Source: Authors' survey applied in December 2018 and January and February, 2019)

\section{CONCLUSIONS}

The study reveals that students residing in the county seats of the analyzed euroregion are aware of their city belonginess to the euroregion of Bihor-Hajdu Bihar in their majority (73,5\% Romanians; 76,5\% Hungarians) as well as being aware what a euroregion means, most respondents definig it as a cooperation structure on both sides of the border. The young population is also knowledgeable of the most popular tourist attractions belonging to their county (of their side of the border) with responses such Aquaticum Debrecen, Hortobagy National park, Nature park Cefa, Hajduszoboszlo and Felix spas, Great Reformed Church of Debrecen, Nymphaea Lotus Aquapark; only five resopondents being able to name attractions from the other side of the border within the boundries of the euroregion (i.e. Felix Spa and Aquaticum Debrecen and Hajduszoboszlo respectively), a scarcity which indicates that a better tourist promotion is needed. Most surveyees $(79,7 \%)$ could name correctly one tourist attraction that 
belongs to the euroregion, more than half $(67,2 \%)$ could provide two attractions and less than a half $(40,6 \%)$ could provide three tourist attractions.

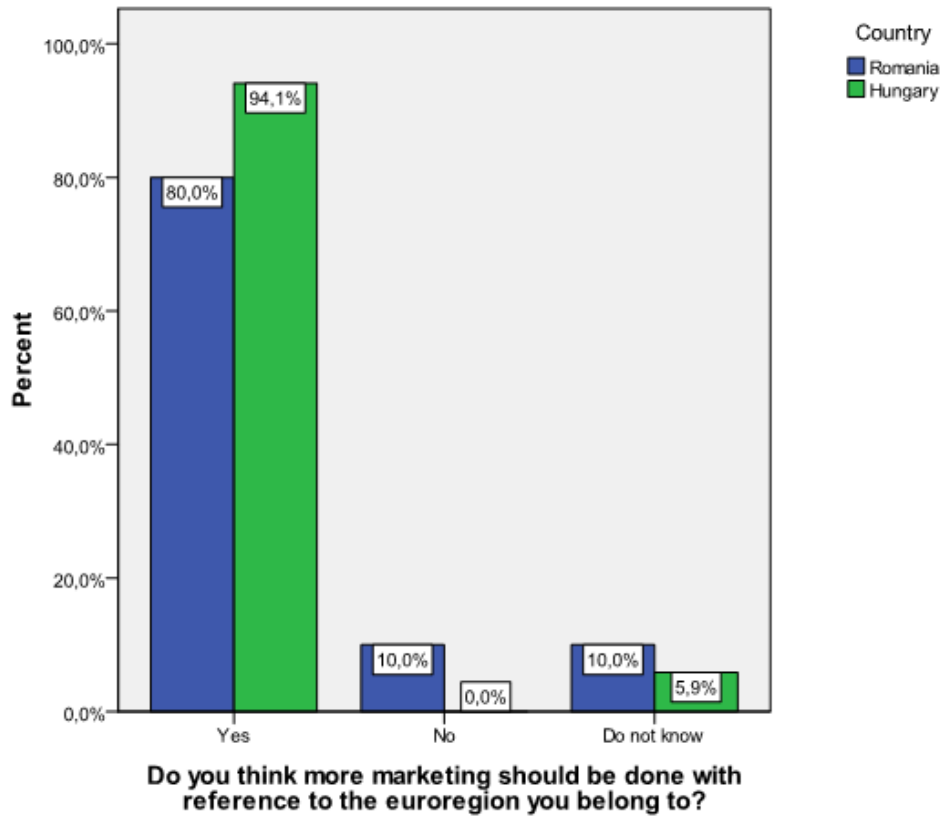

Figure 5. Respondents' answers in relation to the marketing it of the euroregion of Bihor-Hajdu Bihar

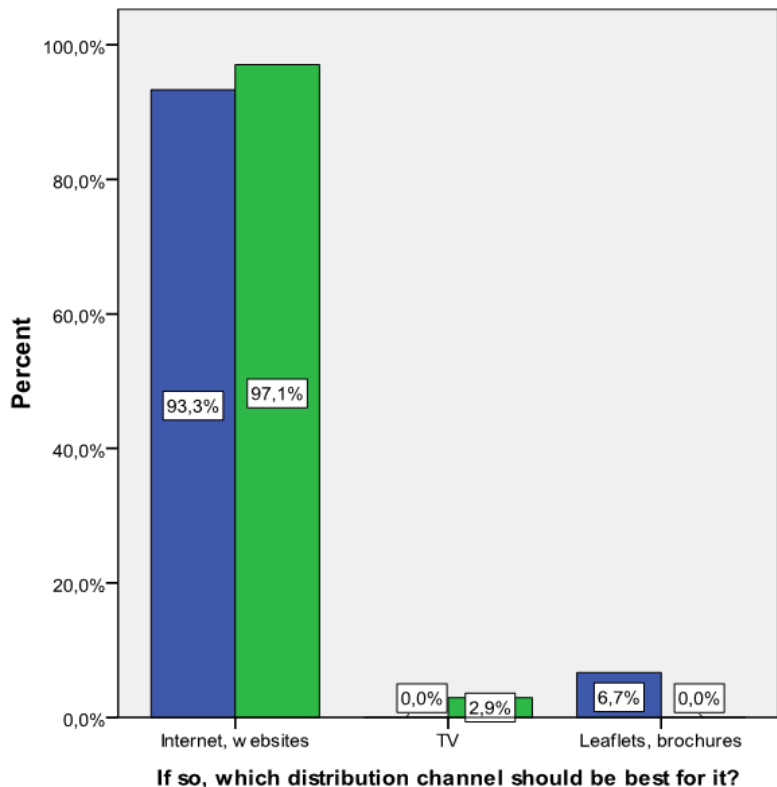

Country

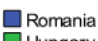

$\square$ Hungary

If so, which distribution channel should be best for it?

Figure 6. Respondents' answers in relation to the best distribution channel for the marketing of the euroregion (Source: Authors' survey applied in December 2018, January and February, 2019)

As far as the activities carried out within the euroregion are concerned, most respondents were unaware of them, claiming that a stronger popularisation as well as 
marketing of the euroregion is needed, mainly through internet and websites, as indicated by $87,5 \%$ of respondents (Romanian and Hungarian put together), so that the euroregion can be perceived as an integrated tourist destination (Wardani \& Widodo, 2020) in its whole. The surveyees' claim for a better marketing shows an eagerness to find out more about its tourist potentialities and opportunities, a shortcome which according to some related economic-focused studies could be overcome by selling the Euroregion as a tourist destination on the market.

\section{REFERENCES}

Badulescu, A. \& Badulescu, D. (2008). Some aspects regarding a tourism development strategy in BihorHajdu-Bihar Euroregion, in Proceedings of the 18th Biennal Congress Tourism \& Hospitality Industry 2006, New trends in Tourism and Hospitality Management.

Czimre, K., Szilagyine (2010). Policy Instruments Promoting and Implementing Cross-Border Cooperations Along the Internal Borders of the European Union, a practical guide - Focus: the Fifth Enlargement, in Horga I. and Suli-Zakar I. (Eds) Cross-Border Partnership with Special Regard to the HungarianRomanian-Ukrainian Tripartite Border, IERS, University of Debrecen Press - University of Oradea Press.

Dasgupta D. (2011). Tourism marketing, Pearson publications.

Fyall A. \& Garrod B. (2005) Tourism marketing - a collaborative approach, Aspects of Tourism, Channel View Publications.

Hall, C.M., (2008). Tourism Planning: Policies, Processes and Relationships, Pearson Prentice Hal.

Halloway J.C. (2004). Marketing for Tourism-Fourth edition, Prentice Hall, Pearson Education Limited.

Ilieș A. (2003). Romania între milenii. Frontiere, areale frontaliere şi cooperare transfrontalieră - Studiu geografic (I), Editura Universității din Oradea.

Ilies D.C., Buhaș R., Ilieș A., Morar C., \& Herman G. (2015). Nymphaea Lotus var. Thermalis (Pârâul Pețea Nature Reserve), Brand Near Extinction of the Băile Felix-Băile 1 Mai (Romania) Spa Tourism System, Geojournal of Tourism and Geosites, year VIII, no1, vol 15.

Lóránt D., Tóth G., Bujdosó Z., \& Remenyik B. (2011). The role of tourism in the development of border regions in Hungary, Romanian Journal of Economics, 32: 2 pp. 109-124. , 16 p.

Lóránt D., Tóth G., Bujdosó Z., \& Remenyik B. (2011). The role of tourism in the development of border regions in Hungary, Romanian Journal of Economics, 32: 2 pp. 109-124. , 16 p.

Lóránt D., Bujdosó Z., \& Tóth G. (2008). Tourism planning in the Hajdú-Bihar - Bihor Euroregion In: SüliZakar, I (szerk.) Neighbours and partners: on the two sides of the border Debrecen, Magyarország, Kossuth Egyetemi Kiadó, (2008) pp. 323-332. , 10 p.

Maghsoodi Tilaki M.J., Hedayati-Marzbali M., Abdullah A., \& Mohsenzadeh M., (2017). Towards Tourism Development: Bridging the Gap between Tourists' Expectations and Satisfaction, Geojournal of Tourism and Geosites, year x, 2017 / 1, volume 19

Studzieniecki T. \& Spiriajevas E. (2019). Cross-Border Tourist Destinations In Europe - Genesis, Essence and Promotion, Proceedings of 46th International Scientific Conference on Economic and Social Development - "Sustainable Tourist Destinations"

Studzieniecki T. (2005). Euroregions-new potential destinations, Tourism Review, vol. 6o/4, pp. 26-32.

Studzieniecki T. \& Soares J.R.R. (2017). Interregional tourism cooperation: A Europe case study, Holos, vol 33, issue 4.

Thimothy D.J \& Teye V.B. (2008). Political Boundaries and Crossborder cooperation in Tourism, in Lew A., Hall CM., Williams A.M. (Eds), A Companion to Tourism, Wiley and Sons.

Thimothy D. J. \& Saarinen Jarkko (2013). Cross-border Cooperation and Tourism in Europe in Panyik E., Buhalis D. (Eds) Trends in European Tourism Planning and Organisation, Aspects of Tourism, Channel View Publications.

Tatar C.F., Czimre K., \& Dehoorne O. (2013). Tourism Life Cycle of Spas from the Romanian-Hungarian Crossborder Area. A Comparative Analysis of the Hajduszoboszlo- Baile Felix/1 Mai Spas, Journal of Travel and Tourism Research, spring -fall 2013.

Uzama A. (2011). Cross-Border Cooperation: Strategies for Marketing Sustainable Development Development Tourism in Northeast Asia, New Delhi, Tatiana Intl. Research.

Wachowiak H. (2006). Tourism and Borders: Contemporary Issues, Policies and International Research, Ashgate.

Wardani Windi NR \& Widodo (2020). Antecedent and Consequence Destination Innovation, Geojournal of Tourism and Geosites, year XIII, vol 28, no. 1.

Wecka B. (2013). Creation of tourist products in transborder region on example of Euroregion Pradziad, in Wyrzykowski J. and Marak J. (Eds) Tourism Role in the Regional Economy, Regional Tourism Product - Theory and Practice, University of Business in Wroclaw.

Submitted:

05.10.2019
Revised:

30.01.2020
Accepted and published online 03.02.2020 